Studia Oecumenica 17 (2017)

DOI: $10.25167 / \mathrm{SOe} / 17 / 2017 / 405-418$

Piotr KroczeK

Wydział Nauk Społecznych UPJPII

\title{
Funkcje prawa w Kościele rzymskokatolickim i Kościele Ewangelicko-Augsburskim w RP
}

\author{
Functions of Law in the Roman Catholic Church \\ and the Evangelical Church of the Augsburg Confession in Poland
}

\begin{abstract}
There is a phenomenon of law in the Christian Churches. The paper describes and compares functions of law, that is, social effects of legal norms from endogenic laws of the two of them: in the Catholic Church and the Evangelical Church of the Augsburg Confession in Poland. It presents functions, such as: creative and organization function, protective and defending function for the personal rights, function of sharing material burdens and distributing the goods, function of regulation of solving conflicts, repressive function, informative and teaching function, educational function, protective and defending function for the matter of faith, salvation function. The conclusion is that functions of law in both Churches are: elaborated and complicated, mixed in their character and can be divided into the typical functions for the Church as a regular society and as a spiritual one, congruent only to some extent.
\end{abstract}

Keywords: law, function of law, legal system, Roman Catholic Church, Evangelical Church of the Augsburg Confession in Poland.

\section{Streszczenie}

W Kościołach chrześcijańskich istnieje zjawisko prawa. Artykuł określa i porównuje funkcje prawa, czyli wywołane przez prawo skutki społeczne zawarte w endogenicznym prawie dwóch Kościołów: Kościoła rzymskokatolickiego i Kościoła Ewangelicko-Augsburskiego w Rzeczpospolitej Polskiej. Te funkcje to: funkcja kreująco-organizacyjna, funkcja ochronno-obronna względem praw osobowych, funkcja podziału materialnych ciężarów i rozkładu dóbr, funkcja regulacji rozwiązywania konfliktów, funkcja represyjna, funkcja informacyjno-nauczająca, funkcja wychowawcza, funkcja ochronno-obronna względem treści wiary, funkcja zbawcza. Wniosek z tych rozważań jest następujący: funkcje prawa w tych dwóch Kościołach są rozbudowane i skomplikowane; funkcje te mają mieszany charakter i mogą być podzielone na funkcje charakterystyczne dla Kościoła jako społeczności ziemskiej i jako społeczności duchowej; funkcje pomiędzy Kościołami są zbieżne ze sobą tylko do pewnego stopnia. 
Słowa kluczowe: prawo, funkcja prawa, system prawny, Kościół rzymskokatolicki, Kościół Ewangelicko-Augsburski w Polsce.

Rzymscy prawnicy obserwując społeczności ludzkie i opierając się na indukcyjnym myśleniu, stwierdzili, że nie ma takiej społeczności, w której nie obowiązywałyby jakieś normy o charakterze prawnym. Obecność tych norm związali oni ściśle i nierozłącznie z naturą człowieka oraz wynikającymi z tej natury procesami międzyludzkimi, które są widoczne w każdej społeczności. Wynik płynący z tej obserwacji zawarli oni w paremii - ubi societas, ibi ius.

Skoro w każdej społeczności ludzkiej można zauważyć fenomen prawa, to można przypuszczać, że prawo wypełnia w każdej z nich identyczne lub zbliżone funkcje. Oznacza to, że prawo wywołuje pewien skutek społeczny (funkcja spełniana) lub też prawo ma w zamiarze prawodawcy wywołać określony skutek społeczny (funkcja oczekiwana) ${ }^{1}$. Sytuacja, w której funkcje oczekiwane są w społeczności tożsame z funkcjami spełnianymi, jest z punktu widzenia prawodawcy sytuacją najbardziej pożądaną. Oznacza ona bowiem, że prawo jest doskonale skutecznym narzędziem w zarządzaniu społecznością. Jednakże w rzeczywistości, czy to z powodu błędów na etapie stanowienia prawa, czy jego wykładni lub stosowania, prawo niejednokrotnie nie realizuje funkcji założonych przez prawodawcę lub realizuje funkcje, których prawodawca nie przewidział².

Fenomen prawa jest także zauważalny we wspólnotach religijnych, np. w Kościołach chrześcijańskich. Wspólnoty te nie tylko uznają prawo Boże naturalne i prawo Boże zawarte w Piśmie Świętym (zob. kan. 199 nr 233), lecz także stanowią dla siebie prawo wewnętrzne. Pozwala to zakładać, że prawo wypełnia w przedmiotowych Kościołach jako społecznościach składających się z wiernych określone funkcje.

Trzeba zaznaczyć, że wszelkie ustalenia prawoznawstwa dotyczące prawa istniejącego na gruncie społeczności o wyłącznie ziemskim pochodzeniu mają jedynie odpowiednie zastosowanie do prawa chrześcijańskich związków wyznaniowych. Konieczność takiego zastrzeżenie wynika z wielu przyczyn. Główną z nich już pośrednio zarysowano. Jest nim początek istnienia Kościoła Chrystusowego na ziemi, który jest związany bezpośrednio z wolą Jezusa Chrystusa. Nie

${ }^{1}$ Por. T. Zieliński, Prawo pracy. Zarys systemu, cz. I, Warszawa - Kraków 1986, 37; Z. ZiemBIŃski, O pojmowaniu celu, zadania, roli i funkcji prawa, „Państwo i Prawo” (1987) z. 12, 19; A. Redelbach, A. Wronkowska, Z. Ziembiński, Zarys teorii państwa i prawa, Warszawa 1992, 270; A. Korybski, L. Leszczyński, A. Pienią̇̇̇e, Wstęp do prawoznawstwa, Lublin 1998, 29. Notabene, w prawoznawstwie polskim podnosi się, że termin prawniczy „funkcja prawa” jest wieloznaczny, zob. I. Bogucka, Funkcje prawa. Analiza pojęcia, Kraków 2000.

${ }^{2}$ Zob. P. KROCZEK, ,Funkcja prawa” jako skutek wprowadzenia do systemu prawnego normy prawnej, „Annales Canonici” 4 (2008), 177.

${ }^{3}$ Cytowane kanony pochodzą z KPK (1983). 
są więc one społecznościami czysto ludzkimi w tym sensie, że nie powstały one wyłącznie na mocy ludzkiej decyzji i z woli ich członków założycieli. To boskie pochodzenie Kościoła Chrystusowego oczywiście nie pozbawia Kościołów chrześcijańskich cech społeczności ludzkich

Wspomniane Kościoły realizują na ziemi wolę Zbawiciela po pierwsze, przez to, że wierni tych związków wyznaniowych wypełniają Jego słowa (Mt 7,24; zob. J 14,23) oraz, po drugie, że nauczają tych słów wszystkie narody (Mt 28,19; zob. Dz 1,8; J 17,18; Mk 16,15; Łk 24,45-48). Element zobowiązania do przestrzegania we wspólnotach nauczania Zbawiciela powoduje, że prawo endogeniczne tych wspólnot zawiera elementy doktrynalnego nauczania tych Kościołów. W rezultacie funkcje prawa chrześcijańskich związków wyznaniowych mogą odbiegać od funkcji prawa społeczności o wyłącznie ziemskiej genezie.

Celem artykułu jest udzielenie odpowiedzi na pytanie o funkcje endogenicznego prawa w dwóch Kościołach ze wspomnianej grupy, a mianowicie w Kościele rzymskokatolickim (KRK) i w Kościele Ewangelicko-Augsburskim w Rzeczypospolitej Polskiej (KEA) ${ }^{5}$. Wybór tych związków wyznaniowych ma w warunkach polskich uzasadnienie statystyczne. KRK jest bowiem największym Kościołem katolickim w Polsce, a KEA największym Kościołem protestanckim 6 .

Poznawanie funkcji prawa, zgodnie z zaprezentowanym wyżej podziałem na funkcje spełniane i funkcje oczekiwane, może odbywać się odpowiednio poprzez obserwację zachowań społeczności wyznaniowych albo przez analizę aktów normatywnych obowiązujących w tych społecznościach. Tę drugą metodę, jako lepiej odzwierciedlającą oficjalne poglądy wspomnianych Kościołów na zagadnienie prawa, obrano w niniejszym artykule. Do osiągnięcia zamierzonego celu badawczego zostanie przeprowadzona analiza podstawowych regulacji KRK i KEA. Będą to odpowiednio: Kodeks prawa kanonicznego z 1983 r. oraz głównie, lecz niewyłącznie, Pragmatyka Służbowa z 1999 r. ${ }^{7}$ oraz Zasadnicze Prawo Wewnętrzne z 1996 r. $^{8}$

${ }^{4}$ Zob. R. SobańsKi, Kościót - prawo-zbawienie, Katowice 1979, 81.

${ }_{5}^{5}$ Mutatis mutandis rozważania dotyczące KRK można odnieść do całego Kościoła katolickiego, czyli także do 22 Katolickich Kościołów Wschodnich. Ich prawo zawarte jest głównie w: Kodeks Kanonów Kościołów wschodnich, Lublin 2002.

${ }^{6}$ Zob. GŁówny Urząd Statystyczny, Wyznania religijne, stowarzyszenia narodowościowe i etniczne w Polsce 2012-2014, Warszawa 2016, odpowiednio 33 i 60.

${ }^{7}$ Pragmatyka Służbowa Kościoła Ewangelicko-Augsburskiego w Rzeczpospolitej Polskiej z 28 listopada 1999 r. zatwierdzona na 4. Sesji Synodu X Kadencji ze zmianami dokonanymi do 10. Sesji Synodu XIII Kadencji (tekst ujednolicony z 1 stycznia 2017 r.), http://bik.luteranie.pl/ files/Prawo/2017-01-01PragmatykaSubowa-tekstujednolicony.pdf (22.02.2017).

${ }^{8}$ Zasadnicze Prawo Wewnętrzne Kościoła Ewangelicko-Augsburskiego w Rzeczpospolitej Polskiej, z 26 października 1996 r. z późn. zm. (tekst ujednolicony z 1 stycznia 2017 r.) http://bik. luteranie.pl/files/Prawo/2017-01-01ZPW-tekstujednolicony.pdf (22.01.2017). 
Typologia funkcji prawa będzie zbudowana w oparciu o rodzaje skutków, które mają postulatywnie wywołać normy prawa lub obszary działania tych norm. Poszczególne funkcje prawa zostaną krótko zaprezentowane i omówione w następującej kolejności: 1) funkcja kreująco-organizacyjna, 2) funkcja ochronn-obronna względem praw osobowych, 3) funkcja podziału materialnych ciężarów i rozkładu dóbr, 4) funkcja regulacji rozwiązywania konfliktów, 5) funkcja represyjna, 6) funkcja informacyjno-nauczająca, 7) funkcja wychowcza, 8) funkcja ochronno-obronna względem treści wiary, 9) funkcja zbawcza.

W funkcjach oznaczonych numerem od 1 do 5 wymienione będą więc te funkcje, które występują także w prawie, które rządzi społecznościami o czysto ziemskim pochodzeniu, np. w prawie państwowym. Funkcje oznaczone numerami od 6 do 9 to te, które są specyficzne (aczkolwiek, jak się wydaje, w przypadku funkcji o numerze 7 - nieekskluzywnie) dla prawa wspólnot religijnych.

\section{Funkcja kreująco-organizacyjna}

Funkcja kreująco-organizacyjna prawa polega głównie na stwarzaniu oraz organizowaniu różnych instytucji, podmiotów lub jednostek organizacyjnych, będących częściami większych całości. Dzięki tej funkcji prawodawca wprowadza innowacje w życie wspólnoty, względnie nadaje istniejącym zjawiskom społecznym prawny wymiar. Wprawdzie podstawą istnienia wymienionych elementów, ich celów i wypełnianych funkcji może być podłoże socjologiczne lub religijno-doktrynalne, to dopiero przepisy prawne dają podstawę do decyzji o powstaniu, kształcie i działaniu tych elementów w większej całości, w tym przypadku Kościołów. Prawa socjologiczne lub doktryna religijna jest wówczas konieczną, aczkolwiek niewystarczającą, zbyt bowiem niedookreśloną podstawą.

Przykładem w tym zakresie może służyć występująca w obu Kościołach podstawowa jednostka organizacyjna, czyli parafia. Parafia jest w całym chrześcijaństwie, zgodnie ze swoją starożytną genezą, uważana za wspólnotę tworzoną naturalnie i spontanicznie poprzez zachowania osób wierzących w Jezusa i gromadzących się na łamaniu chleba i na modlitwach (Dz 2,42). Jednak do powstania parafii w taki sposób, aby była ona uznana w Kościele, czyli nadanie jej bytu prawnego, określenia jej praw i obowiązków oraz usytuowania w strukturze Kościoła, potrzebna jest decyzja władzy kościelnej wyrażona na podstawie przepisów prawnych, które przyznają tej władzy przedmiotową kompetencję. Zachowanie wiernych pragnących we wspólnocie praktykować wiarę nie wystarczy. 
W prawie KRK o koniecznym istnieniu w Kościele parafii stwierdza się w kan. $374 \S 2$ : „Każda diecezja lub inny Kościół partykularny powinny być podzielone na odrębne części, czyli parafie". Kompetencje do erygowania parafii przyznaje się biskupowi diecezjalnemu (kan. 515 § 2). Analogiczną treść normatywną ma § 32 Zasadniczego Prawa Wewnętrznego KEA: „Diecezje tworzą Parafie znajdujące się na określonym terenie”. Kompetencje do podjęcia decyzji ma Konsystorz ( $\$ 1$ ust. 2 RP).

\section{Funkcja ochronno-obronna względem praw osobowych}

Funkcja ochronno-obronna prawa ma na celu stwierdzenie i utrzymanie w stanie nienaruszonym praw osoby ludzkiej i praw wiernego. Prawa te mają podstawę odpowiednio w przyrodzonej godności człowieka lub fakcie przyjęcia przez osobę chrztu świętego. Prawa te wynikają więc z Bożego prawa naturalnego lub prawa Bożego pozytywnego (zob. kan. 199 nr 2). Prawa mające taką genezę są przez prawo stwierdzane.

Prawa osobowe mogą także wywodzić się z prawa, które w nomenklaturze kanonicznej określa się terminem: „,prawo czysto kościelne”. Jest to prawo rozumiane jako prawo stanowione przez kompetentną władzę, które nie zawiera w sobie dwóch pierwszych z wymienionych praw (zob. kan. 11). Ten podział zaproponowany w Kodeksie prawa kanonicznego może być zastosowany do praw osobowych zawartych w prawie ewangelickim. Prawa osobowe nie są stwierdzane, lecz nadawane przez władzę kościelną.

Dodać można, że utrzymanie w stanie nienaruszonym praw osobowych (niezależnie od pochodzenia) może polegać także na eliminowaniu lub zmniejszaniu prawdopodobieństwa wystąpienia zachowań zagrażających wspomnianym prawom poprzez kryminalizację i penalizacją ich zagrożeń.

Przykładem ochrony prawa osobowego wypływającego z prawa naturalnego jest kan. 215 stanowiący, iż wierni mają prawo swobodnego zakładania stowarzyszeń. Z kolei obrona naturalnego prawa człowieka do życia znajduje się w normie sankcjonującej zawartej w kan. 1397 i penalizującej zabójstwo, czy też w normie z kan. 1398 penalizującą aborcję. Z kolei prawo ewangelickie chroni naturalne prawo do wolności religijnej, zachęcając duchownych do „pełnej tolerancji i szacunku dla inaczej wierzących chrześcijan” (§ 187 PS).

Ochrona i obrona praw osobowych wypływających z prawa Bożego stanowionego jest przykładowo zawarta w prawie kanonicznym - w przepisach dotyczących prawa do wynagrodzenia (kan. $281 \S 1$; por. np. kan. 231 § 2). To samo ma na celu przepis $\S 198$ ust. 1 lit. a Pragmatyki Służbowej, gdzie jest mowa o ,prawie do przychodu ze służby”. 
Gdy chodzi o prawa kreowane przez prawodawcę kościelnego, to troska o nie jest dość oczywista w kontekście źródła ich ustanowienia. Dla egzemplifikacji można podać prawo do przejścia na emeryturę - w KEA wszyscy duchowni, a więc diakoni, prezbiterzy i biskupi niezależnie do pełnionych funkcji, mają prawo przejść na emeryturę w wieku 65 lat (§ 19 ZPW), a w KRK proboszczowie i biskupi w wieku 75 lat (kan. $538 \S 3$ i kan. $401 \S 1$ ). Pytanie oto, czy przedmiotowe prawo jest jednocześnie obowiązkiem dla wymienionych osób nie ma znaczenia dla głównego nurtu rozważań.

\section{Funkcja podziału materialnych ciężarów i rozkładu dóbr}

Prawo kanoniczne i prawo ewangelickie zajmują się podziałem materialnych ciężarów wynikających z kosztów funkcjonowania społeczności wiernych oraz rozkładem dóbr materialnych wypracowanych przez tę społeczność lub poszczególnych jej członków zwykle poza działalnością kościelną.

W KRK omawianą funkcję realizują przepisy dotyczące podatków wewnątrzkościelnych (zob. kan. 264 § 1; kan. 126). Co do zasady podatki mają być zbierane od publicznych osób prawnych (kan. 1263). Jednakże możliwe jest także ustanowienie takiego obowiązku na osobach fizycznych (kan. $1263 \mathrm{w}$ związku z kan. 222 § 1; zob. kan. $945 \S 1$ i kan. 1264 nr 2). Zebrane środki powinny być przeznaczane na różne potrzeby Kościoła, a głównie na: sprawowanie kultu, prowadzenie dzieł apostolstwa oraz miłości, a także do tego, co jest konieczne do godziwego utrzymania szafarzy (kan. $222 \S 1$ ).

Z kolei prawo KEA stanowi, że parafia ma zaspokajać swoje potrzeby materialne z dochodów uzyskanych ze swojego majątku. Innym źródłem finasowania wspólnoty są różne składki i ofiary, dochody z działalności gospodarczej i fundacji (§ 25 ZPW). Parafianie ewangeliccy są zobowiązani do opłacania składki kościelnej ( $\$ 248$ PS; zob. $\S 7$ ust. 1 oraz $\S 3$ ust. 1 RP ${ }^{9}$ ).

\section{Funkcja regulacji rozwiązywania konfliktów}

Realizacja funkcji prawa, którą jest rozwiązywanie konfliktów mających miejsce we wspólnocie wierzących, jest, co do zasady, w Kościołach chrześcijańskich związana z wykonywaniem przez Kościół władzy królewskiej ( $m u$ -

${ }^{9}$ Regulamin Parafialny z 18 lutego 2000 r. z późn. zm. (tekst ujednolicony z 24 czerwca 2015 r.) http://bik.luteranie.pl/files/Prawo/2015-06-24RegulaminParafialnytekstjednolityBIK.pdf $(22.02 .2017)$. 
nus regendi) Jezusa Chrystusa. Opierając się na tym doktrynalnym fundamencie, prawo kanoniczne reguluje instytucje np. trybunałów kościelnych (zob. kan. 1419-1445) i procedur różnych procesów kanonicznych (zob. Księga VII KPK). Warto zauważyć, że prawu kanonicznemu znane są instytucje: mediatora (kan. $1773 \S 1)$ i arbitra (kan. $510 \S 3$ ), które mogą być użyte do rozwiązywanie konfliktów.

Prawo ewangelickie z kolei zawiera przepisy regulujące działanie Sądu Dyscyplinarnego (§ $44 \mathrm{PD})$ oraz określa sytuacje, w których ten sąd jest kompetentny do wydania orzeczeń (szczególnie $\S 1$ ust. $1 \mathrm{PD}$ ). W prawie KEA można także znaleźć inne regulacje dotyczące konfliktów, np. procedury o charakterze administracyjnym (§ 11 ust. 3 ZPW oraz $§ 70$ ust. 15 w zw. z $§ 66$ ust. 1 ZPW).

\section{Funkcja represyjna}

Funkcja represyjna prawa wynika z potrzeby zapewnienia mu należytego szacunku i w konsekwencji także odpowiedniej efektywności normom prawnym. Prawodawca musi więc łączyć normę zakazującą albo nakazującą określone zachowanie z sankcją, czyli przykrością dla podmiotów podejmujących zachowania odmienne od przewidzianych. Funkcja represyjna bywa także konsekwencją funkcji regulacji rozwiązywania konfliktów czy funkcji ochronno-obronnej praw osobowych - wówczas ma na celu wymierzenie sprawiedliwości.

W prawie kanonicznym prawodawca przewidział szeroki wachlarz środków represyjnych. Głównie są to sankcje karne, czyli: kary lecznicze (cenzury: ekskomunika, interdykt, suspensa - kan. 1331-1333) i kary ekspiacyjne, takie jak np.: pozbawienie władzy, urzędu, zadania, prawa (kan. 1336 § 1). Do powyższego podziału trzeba także włączyć środki karne i pokuty. Wprawdzie nie są one karami sensu stricto, lecz mają związek z zachowaniem niezgodnym z normą kanoniczną. Te pierwsze mają na celu zabezpieczenie porządku społecznego we wspólnocie przed popełnieniem przestępstwa, a te drugie mogą zastępować karę lub ją zwiększyć (kan. 1312 § 3) ${ }^{10}$.

Gdy chodzi o prawo KEA, to prawo to przewiduje sankcje za róże wykroczenia, głównie dyscyplinarne (zob. np. § 15 ust. 5 i ust. 9 ZWP; $\S 6$ ust. 2 lit. c PS). Przepisy dyscyplinarne Kościoła Ewangelicko-Augsburskiego w RP z 15 października 2016 r. ${ }^{11}$ zawierają wyliczenie kar. Są nimi, przykładowo, ograniczenia praw socjalno-bytowych, przeniesienie na inne stanowisko, pozbawienie prawa

\footnotetext{
10 J. Syryjczyk, Sankcje w Kościele. Część ogólna. Komentarz, Warszawa 2008, 57.

${ }^{11}$ Przepisy dyscyplinarne Kościoła Ewangelicko-Augsburskiego w RP z 15 października 2016 r., https://bik.luteranie.pl/files/Prawo/2017-01-01Przepisydyscyplinarnetekstujednolicony.doc. pdf (20.01.2017) (dalej: PD 2016).
} 
sprawowania urzędu ( $\$ 4$ ust. 1 PD 2016). Funkcję represyjną pełnią także środki dyscyplinujące, również stosowane wobec osób popełniających wykroczenia dyscyplinarne ( 3 ust. 1 PD 2015). Są to przykładowo: pouczenie, upomnienie, nagana ( $\$ 3$ ust. 2 PD 2015) $)^{12}$.

\section{Funkcja informacyjno-nauczająca}

Funkcję informacyjno-nauczającą wypełnia prawo kanoniczne i prawo ewangelickie głównie poprzez definicje legalne zawarte w przepisach. Definicje te nie są oryginalne, lecz przenoszą, niejednokrotnie dosłownie, na forum prawne treść źródeł doktrynalnych. Prawo wówczas staje się kolejnym sposobem do szerzenia nauki wiary.

Przedmiotową funkcję można zobrazować definicją chrztu świętego obowiązującą w prawie obu Kościołów. W prawie rzymskich katolików w kan. 849 stanowi się: „Chrzest, brama sakramentów, [jest] konieczny do zbawienia”. To sformułowanie odpowiada treścią zdaniu z nr 1213 Katechizmu Kościoła Katolickiego, w którym naucza się, że „chrzest święty jest (...) bramą otwierającą dostęp do innych sakramentów".

Z kolei Kościół ewangelicki naucza w Augsburskim wyznaniu wiary, że sakrament chrztu świętego jest aktem, który jest „konieczny do zbawienia, gdyż przezeń ofiarowana jest łaska Boża"13. Identyczne sformułowanie zawiera $§ 68$ ust. 2 Pragmatyki Służbowej.

\section{Funkcja wychowawcza}

Wprawdzie, jak twierdzili rzymscy prawnicy, ius non docet, sed iubet (,,prawo nie uczy, lecz rozkazuje"), to od prawa Kościołów chrześcijańskich z racji specyfiki więzi łączącej członków tych społeczności, czyli wiary, można spodziewać się wypełniania także funkcji wychowawczej. Jezus Chrystus wyswobodził przecież ludzi ku wolności (Ga 5,1). Wiara w Niego jako postawa człowieka musi być aktem wolnym, któremu przymus jest obcy (kan. 748 § 2). Innymi słowy, prawo będzie nie tylko bezwzględnie nakazywać określone zachowania i łączyć je z represjami (funkcja represyjna prawa), lecz ma zachęcać do takich zachowań

12 PD2015 - Przepisy dyscyplinarne Kościoła Ewangelicko-Augsburskiego w RP z 13 listopada 2015 r. (https://bik.luteranie.pl/files/Prawo/2015-11-13PrzepisyDyscyplinarneujednoliconyRS. pdf), (20.01.2017), których przepisy zawarte w Dziale II nadal obowiązują.

${ }^{13}$ F. Melanchton, Wyznanie augsburskie, tłum. J.W. JaCKOwsKI, w: Księgi wyznaniowe Kościoła luterańskiego, Bielsko-Biała 2011, nr IX: O chrzcie, 146. 
członków wspólnoty. Prawo wypełniając omawianą funkcję, będzie kształtować trwałe chrześcijańskie postawy, wyrabiać chrześcijańskie cnoty, względnie apelować do wiernych o zachowania prawidłowe z punktu widzenia zasad wiary, czy też dawać dobre rady w tym zakresie.

Mając na względzie funkcję wychowawczą prawa, prawodawca w KRK nie zawsze posługuje się formą dyrektywalną przepisów. Zwykle także nie załącza do norm sankcji działających forum externum. Natomiast prawodawca adresatów normy: „usilnie [o coś] prosi” (kan. $401 \S 2$ ), „usilnie [coś] zaleca” (kan. 945 $\S 2$; kan. 1065 § 1), względnie adresaci normy są ,proszeni” (kan. 538 §). Tym samym prawodawca wychowuje ich, licząc na wypełnianie określonych zachowań nie z obawy przed złamaniem normy (co nota bene wiąże się zwykle z winą moralną, czyli grzechem) ani z powodu obawy przed sankcją zewnętrzną, czyli odpowiedzialnością ad poenam. Prawodawca liczy na to, że wierni podążą za normą z pragnienia pełnego i wiernego praktykowania swojej wiary. Ta postawa wypływać powinna z miłości do Jezusa i Jego Kościoła.

Wprawdzie zgodnie z przedstawionym wyżej założeniem prawo każdego Kościoła chrześcijańskiego powinno tę wychowawczą funkcję wypełniać, to w prawie ewangelickim jest ona trudna do zauważenia. Przepisy aktów normatywnych są zredagowane głównie w formie zdań bezwzględnie nakazujących zachowanie, tak jak: „Biskupi i duchowieństwo parafialne odpowiadają za życie komunijne Kościoła” (§ 93 PS), czy te „należy nieustannie zachęcać” (§ 88 ust. 2 PS), „należy zadbać” (§ 90 PS). Niekiedy przepisy określają wprost „zobowiązanie" do opisanego w prawie zachowania (zob. np. § 24 ust. 1 i ust. 2 PS). Wyjątek stanowi przepis $\S 98$ PS, w którym „zaleca się” pewne rozwiązanie. Jest to jednak zalecenie dotyczące wyboru sprawy technicznej (sejfu), a nie dotyczące bezpośrednio zachowania wiernego Kościoła. Jedynie w objaśnieniach do przepisów prawa zawartych w okólnikach expressis verbis „zaleca się” pewne rozwiązania ${ }^{14}$. Należy więc stwierdzić, że prawo ewangelickie wypełnia funkcje wychowawczą w sposób minimalny.

Aby lepiej pokazać różnicę w omawianym zakresie pomiędzy prawem kanonicznym a ewangelickim można przykładowo podać - wyżej przywołany - przepis z $§ 19$ Zasadniczego Prawa Wewnętrznego: „Wszyscy duchowni Kościoła przechodzą na emeryturę w wieku 65 lat”. Analogicznym przepisem jest zdanie w Kodeksie prawa kanonicznego: „Biskup diecezjalny, który ukończył siedemdziesiąty piąty rok życia, jest proszony o złożenie na ręce Papieża rezygnacji z zajmowanego urzędu" (kan. 401 § 1; zob. także kan. 354 i kan. 538 § 3). Z jed-

${ }^{14}$ Konsystorz Kościoła Ewangelicko-Augsburskiego w RP, Okólnik 4/2015 z 11 kwietnia 2015 r., Zasady reprezentacji parafii w znowelizowanym Regulaminie Parafialnym obowiazujacym od 1 stycznia $2015 \mathrm{r}$. 
nej strony jest więc wyrażenie bezwzględnie wiążące, aczkolwiek możliwe są odstępstwa od normy wynikające z innych przepisów, a z drugiej - prośba.

\section{Funkcja ochronno-obronna względem treści wiary}

Ochronno-obronna funkcja wiary rozumianej jako treści dogmatyczne przechowywane i przekazywane przez Kościół jest, co do zasady, zbliżona w przedmiocie metod i celów działania do przedstawionej wyżej funkcji ochronno-obronnej prawa względem praw osobowych.

W KRK odpowiedzialność za depozyt wiary i jego przekazywanie ponoszą w szczególności: biskup rzymski, jako najwyższy Pasterz i Nauczyciel wszystkich wiernych (kan. $749 \S 1$ ); kolegium biskupów, w sytuacji, gdy biskupi wypełniają urząd nauczycielski zebrani na soborze powszechnym jako nauczyciele i sędziowie wiary i moralności (kan. 749 § 2); biskupi (czy to pojedynczy, czy też zebrani na konferencjach episkopatu lub na synodach partykularnych) jako autentyczni nauczyciele i mistrzowie wiary (kan. 753). Także proboszczowie są zobowiązani zatroszczyć się o to, ażeby przybywającym w parafii głoszone było nieskażone słowo Boże (kan. 528 § 1).

W prawie kanonicznym funkcję obrony wiary przejmują przepisy opisujące przestępstwa przeciwko wierze. Jest to przestępstwo herezji polegające na uporczywym, po przyjęciu chrztu, zaprzeczaniu jakiejś prawdzie, w którą należy wierzyć wiarą boską i katolicką, albo uporczywe powątpiewanie o niej (kan. 751), oraz schizma - przestępstwo polegające na nieuznawaniu zwierzchnictwa biskupa rzymskiego (kan. 751). Wydawać by się mogło, że schizma nie narusza bezpośrednio wiary, lecz jest skierowana przeciwko więzom pełnej wspólnoty kościelnej. Jednakże schizmę konstytuuje takie nieposłuszeństwo względem papieża, które neguje jego prymat ${ }^{15}$. A prymat - jak to określono na Soborze Watykańskim I w Encyklice Pastor eaternus ${ }^{16}$ - polega na tym, że papież jest nauczycielem wszystkich chrześcijan, ma więc prymat nauczania ${ }^{17}$, a także posiada on pełnię władzy pasterzowania, rządzenia i kierowania Kościołem powszechnym, czyli ma prymat jurysdykcji ${ }^{18}$. Tak rozumiany prymat jest dogmatem wiary. Wymienione przestępstwo kanoniczne przewiduje kary kanoniczne (zob. kan. 1364 § 1 i 2).

15 Por. J. SyryjczyK, Kanoniczne prawo karne. Częśś szczególna, Warszawa 2003, 28.

16 Sacrosanctum Concilium Oecumenicum Vaticanum I, Sessio IV, 18.07.1870, Constitutio dogmatica I Pastor aeternus de Ecclesia Christi, w: H. DenZINGER, A. SchönmeTZER, Enchiridion symbolorum, definitionum et declarationum de rebus fidei et morum, (dalej: DS), P. HüNERMANN (red.), Bologna 1995, nr 3050-3075; A. Baron, H. Pietras (RED.), Dokumenty soborów powszechnych. Tekst łaciński, polski, t. IV: 1511-1870, Kraków 2004, 912-927.

17 DS 3065.

${ }^{18}$ DS 3053-3059. 
Z kolei prawo ewangelickie określa obowiązki różnych podmiotów na tym polu. Dotyczą one podmiotów indywidualnych i zbiorowych. Polegają one na czuwaniu nad „zachowaniem czystości nauki Kościoła”, „czystości zwiastowania Słowa Bożego". Tymi obowiązkami związani są duchowni - proboszczowie (§ 36 ust. 2 ZPW; $\S 24$ ust. 1 PS) i biskupi ( $\$ 16$ ust. 1 PS) oraz Rady Parafialne (§ 34 pkt 1 ZPW) i Synod Kościoła ( 64 pkt 1 ZPW). Prawo ewangelickie także przewiduje sankcje za naruszenie obowiązków w omawianym zakresie. Mogą być one wymierzone nie tyle za odstępstwo od wiary, czyli za jej wypaczenie lub jej negowanie, lecz za niedopełnienie obowiązków podmiotów odpowiedzialnych za obronę i ochronę wiary ( $§ 1$ ust. 1 PD 2016). Pragmatyka Służbowa wzywa jedynie do zachowania wierności Bogu i Kościołowi w osobistym życiu małżonkom żyjącym w małżeństwach mieszanych (§ 133 PS).

\section{Funkcja zbawcza}

Funkcja zbawcza prawa w kontekście Kościołów chrześcijańskich nie może być oczywiście rozumiana jako soteriologia prawa. Ani KRK, ani KEA nie mogłyby uznać stwierdzenia „prawo zbawia” za prawdziwe. Zbawicielem jest Jezus Chrystus. Jest to podstawowa prawda chrześcijaństwa. Wprawdzie prawo nie zbawia, lecz prawo obowiązujące w Kościołach (KRK i KEA) jest narzędziem, przez które Kościoły te przybliżają i prowadzą swoich wiernych do zbawienia.

Z punktu widzenia katolickiego ostateczny zbawczy cel prawa musi przyświecać procesowi powstania, wykładni i zastosowania każdego przepisu. Nie ma miejsca w systemie prawa kościelnego na normy nieistotne pod względem przedmiotowej funkcji. W tym sensie funkcja zbawcza obejmuje i jakby zawiera w sobie inne funkcje prawa. Funkcja zbawcza warunkuje sens innych funkcji prawa. Przepisy prawne zawierające normy nieistotne z punktu widzenia zbawczego są zbędne. Choć formalnie obowiązują, to można zaryzykować stwierdzenie, że ich przestrzeganie nie może wiązać się z odpowiedzialnością ad culpa nawet, jeżeli są one ustanowione jako prawo powszechne dla całego Kościoła. Po prostu brak takim normom raison d'être w Kościele.

Niekiedy ta zbawcza funkcja prawa jest zawarta implicite $\mathrm{w}$ przepisach tak głęboko, że trudno ją prima facie stwierdzić. Taka sytuacja ma miejsce przykładowo, gdy chodzi o normy regulujące terminy (np. kan. $203 \S 1$; kan. $1465 \S 1$ ). Wówczas ich użyteczność zbawczą można wyprowadzić z konieczności sprawnego zarządzania Kościołem jako instytucją.

$\mathrm{O}$ wiele łatwiej zauważyć zbawczą funkcję prawa w przepisie dopuszczającym katolików do sakramentów in periculo mortis (kan. $566 \S 1$ ), a nawet 
ochrzczonych katolików (kan. $844 \S 4$ ) oraz nieochrzczonych (kan. 865 § 1; kan. $867 \S 1$ ). Wówczas właśnie ze względu na zbawienie, pomimo okoliczności wyłączających w sytuacjach zwykłych możliwość przyjęcia sakramentu, prawodawca dopuszcza, a nawet czyni przyjęcie sakramentu w pełni godziwym. Niekiedy funkcja zbawcza prawa kanonicznego jest wprost wyrażona w prawie kanonicznym explicite, przykładowo w kan. $1736 \S$ 1, kan. 1737 § 1, a zwłaszcza w kan. 1752.

Z kolei luteranie nie odnotowują w swoim prawie tak jasno celu funkcji zbawczej prawa, jak to robią katolicy. Nie odwołują się do zasady ukierunkowującej prawo wprost na salus animarum, choć $\mathrm{w}$ chrześcijaństwie pojawiła się ona wyraźnie za sprawą Ivo z Chartres już w XI w. ${ }^{19}$ Jednakże także ich prawo wewnętrzne organizuje działalność zbawczą Kościoła, regulując przykładowo sprawę sakramentu chrztu ( $\$ 68-\S 72$ PS), który jest konieczny do zbawienia ( $\$ 68$ PS). Tę zbawczą funkcję prawa ewangelickiego widać także w nakazie skierowanym do duchownych, aby dobrze wykorzystywali powierzony dar łaski, przez który realizowana jest we wspólnocie służba posługiwania Słowa i Sakramentów (§ 7 PS w związku z § 10 ust. 1 PS).

\section{Zakończenie}

Z przedstawionej analizy i podanych przykładów wysnuć można kilka wniosków. Po pierwsze, funkcje prawa zarówno w KRK, jak i w KEA są rozbudowane. Oznacza to, że prawo nie pełni w tych wspólnotach roli podrzędnej, lecz jest instrumentem zarządzania wspólnotą, od którego oczekuje się efektywności.

Po drugie, funkcje prawa w KRK i KEA można podzielić na takie, które są charakterystyczne dla funkcji prawa społeczności czysto ziemskich (np. prawa państwowego), oraz na takie, które są specyficzne dla prawa kościelnego, czyli prawa społeczności o nadprzyrodzonej genezie.

Po trzecie, w prawie KRK bardziej niż w prawie KEA rozbudowane są takie funkcje, jak funkcja wychowawcza, czy funkcja zbawcza. Pod tym względem prawo ewangelickie odstaje od prawa kanonicznego, przesuwając się $\mathrm{w}$ stronę prawa czysto ziemskich społeczności. Nie zatraca ono jednak chrześcijańskiej specyfiki.

19 Ivo CARnotensis, Epistula 60, w: TENŻE, Opera omnia, PL 162, 74: Cum ergo omnis institutio ecclesiasticarum legum ad salutem referenda sit animarum. 


\section{Bibliografia}

Bogucka I., Funkcje prawa. Analiza pojęcia, Kraków 2000.

Codex Canonum Ecclesiarum Orientalium auctoritate Ioannis Pauli PP. II promulgatus, 18.10.1990, „Acta Apostolicae Sedis” 82 (1990), s. 1045-1353; tekst łacińsko-polski: Codex Canonum Ecclesiarum Orientalium auctoritate Ioannis Pauli PP. II promulgatus, Kodeks kanonów Kościołów wschodnich. Promulgowany przez papieża Jana Pawła II, wydanie łacińsko-polskie, Lublin 2002.

Codex Iuris Canonici auctoritate Ioannis Pauli PP. II promulgatus, 25.01.1983, „Acta Apostolicae Sedis” 75 (1983), pars II, s. 1-301; tekst łacińsko-polski: Kodeks prawa kanonicznego, przekład zatwierdzony przez Konferencję Episkopatu Polski, Poznań 1984.

GŁówny URząd Statystyczny, Wyznania religijne, stowarzyszenia narodowościowe $i$ etniczne w Polsce 2012-2014, Warszawa 2016.

Ivo Carnotensis, Epistula 60, w: tenże, Opera omnia, accurante J.P. Migne, Patrologiae cursus completus. Series Latina, 162, Parisiis 1854, kol. 70-75.

Konsystorz KościoŁa Ewangelicko-Augsburskiego w RP, Okólnik 4/2015 z 11 kwietnia 2015 r., Zasady reprezentacji parafii w znowelizowanym Regulaminie Parafialnym obowiazujacym od 1 stycznia $2015 \mathrm{r}$.

KRoczeK P., „Funkcja prawa” jako skutek wprowadzenia do systemu prawnego normy prawnej, „Annales Canonici” 4 (2008), s. 173-180.

Melanchton F., Wyznanie augsburskie, tłum. J. W. JaCKOwsKI, w: Księgi wyznaniowe Kościoła luterańskiego, Bielsko-Biała 2011, s. 143-163.

Pragmatyka Stużbowa Kościoła Ewangelicko-Augsburskiego w Rzeczpospolitej Polskiej z 28 listopada 1999 r. zatwierdzona na 4. Sesji Synodu X Kadencji ze zmianami dokonanymi do 10. Sesji Synodu XIII Kadencji (tekst ujednolicony z 1 stycznia 2017 r.), http://bik.luteranie.pl/files/Prawo/2017-01-01PragmatykaSubowa-tekstujednolicony.pdf (22.02.2017).

Przepisy dyscyplinarne Kościoła Ewangelicko-Augsburskiego w Rzeczypospolitej Polskiej z 15 października 2016 r. Tekst przyjęty uchwata nr 18/2016 Synodu Kościoła, http://bik.luteranie.pl/files/Prawo/2017-0101Przepisydyscyplinarnetekstujednolicony.doc.pdf (20.01.2017).

Przepisy dyscyplinarne Kościoła Ewangelicko-Augsburskiego w Rzeczypospolitej Polskiej z 13 listopada 2015 r., https://bik.luteranie.pl/files/Prawo/2015-11-13PrzepisyDyscyplinarneujednoliconyRS.pdf (20.01.2017).

Redelbach A., Wronkowska A., Ziembiński Z., Zarys teorii państwa i prawa, Warszawa 1992. 
Regulamin Parafialny z 18 lutego 2000 r. z późn. zm. (tekst ujednolicony z 24 czerwca 2015 r.) http://bik.luteranie.pl/files/Prawo/2015-06-24RegulaminParafialnytekstjednolityBIK.pdf (22.02.2017).

Sacrosanctum Concilium Oecumenicum Vaticanum I, Sessio IV, 18.07.1870, Constitutio dogmatica I Pastor aeternus de Ecclesia Christi, w: H. DeNZINGER, A. SCHÖNMETZER, Enchiridion symbolorum, definitionum et declarationum de rebus fidei et morum, P. HüNERMANn (red.), Bologna 1995, nr 3050-3075; A. Baron, H. Pietras (red.), Dokumenty soborów powszechnych. Tekst taciński, polski, , t. IV: 1511-1879, Kraków 2004, s. 912-927.

Sobański R., Kościót - prawo - zbawienie, Katowice 1979.

SyryjczyK J., Kanoniczne prawo karne. Część szczególna, Warszawa 2003.

Zasadnicze Prawo Wewnętrzne Kościoła Ewangelicko-Augsburskiego w Rzeczpospolitej Polskiej, z 26 października 1996 r. z późn. zm. (tekst ujednolicony $z 1$ stycznia 2017 r.), http://bik.luteranie.pl/files/Prawo/2017-01-01ZPW-tekstujednolicony.pdf (22.01.2017).

ZIEMBIŃski Z., O pojmowaniu celu, zadania, roli i funkcji prawa, „Państwo i Prawo" (1987) z. 12, s. 15-27.

Zieliński T., Prawo pracy. Zarys systemu, cz. I, Warszawa - Kraków 1986. 